\title{
Protection of landscape-recreational complex of cities
}

\section{Novakovska, Candidate of Sciences (Economics) National Aviation University}

The purpose. To study processes of formation of landscape-recreational complex of cities, actual state of use of the specified lands, and also directions of optimization of land-use. Methods. Generalizations, simulation. Results. Principles of incorporation of aspects of lands in uniform landscape-recreational terrains, and also ecological, economic and legal mechanisms of overcoming of the crisis phenomena concerning protection and use of these lands are offered. Conclusions. System of protection of landlandscape complex should be based on ecological monitoring, including ecologo-legal provision and ecological audit of natural management (ecological mechanism). Economical mechanism of protection of lands needs to be improved. It should be linked to rent policy in land-use and compensating payments caused by loss of valuable lands.

Key words: visual environment, recreation, protection of lands, ecological monitoring, ecological audit.

Sustainable development of urban agglomerations is largely due to the rational use of the potential of the resource base for socio-economic uplift, environmental protection and conservation of natural resources of the respective territories. First of all, it concerns land use, the organization and regulation of which should be aimed not only at ensuring the effective use of land and resource potential, but also to prevent or significantly reduce the negative impact of anthropogenic activity, which leads to pollution, depletion and degradation of land. Environmental legislation indicates the need for comprehensive protection of productive lands, forest areas, especially protected areas from unjustified extraction or change of intended purpose [2].

As part of the land of cities, the landscape and recreational territories play a special role in maintaining and increasing the health of the population. According to city-planning legislation, they include suburban forests, forest parks, forest bands, reservoirs, recreation areas and resort areas, agricultural land use. Together with parks, gardens, squares, boulevards, which form part of settlement territories, they form a system of landscaping and recreation zones [3].

Agricultural land within cities includes areas of individual housing development, private households, collective and individual gardens, public gardens, that is, predominantly land tenure and land use of citizens directly related to recreational purposes. Agricultural activities carried out by agricultural enterprises are carried out only on $1,7 \%$ of the total area of such land in cities. Consequently, the attribution of agricultural land in cities to the landscape and recreational territories is quite justified. Dynamics of the land area of the landscape-recreation complex for 2005-2015 is characterized by the data of the table. Over the decade (2005-2015), the total area of the city's lands increased by 45.5 thousand hectares, and the area of landscapes of the landscape-recreation complex increased by only 21.8 thousand hectares. This is explained by the fact that the increase for this period concerned mainly areas of built-up land, the size of which increased by 26.5 thousand hectares.

As the analysis shows, in recent years, in large cities (Kiev, Kharkiv, Odesa) the area of agricultural land has decreased as a result of its allocation to urban development. In 2006-2010, the area under the forests and other forested areas in the city of Kyiv declined by 510 hectares due to their extraction for nonagricultural needs.

Coastal areas of water bodies are engaged in the construction of individual cottages and health facilities. We are carrying out of territories in floodplains of rivers. Significant damage to the environment is caused by the unauthorized construction and occupation of public gardens, other sections of green spaces for multistorey construction. The norms of the legislative acts on the prohibition of the cutting of trees in urban areas are not fulfilled.

It is believed that the current ecological situation in Ukraine can be characterized as a crisis that was formed over a long period due to neglect of the objective laws of development and reproduction of the natural resource complex of the country. The lack of effective legal and economic mechanisms of nature management and the low level of environmental consciousness of the society led to significant degradation 
of the environment, excessive pollution of water, air and land, and the accumulation of large quantities of harmful, including highly toxic waste products [7].

In particular, the overcoming of crisis phenomena in the use of nature in general and in land use is related to the introduction of a system of ecological, legal and economic mechanisms for the organization of rational use and protection of the land fund of the country. As you know, one of the decisive directions of the functioning of the land protection institute is to prevent unreasonable seizure of agricultural and forestry land. Within the cities, agricultural land occupy $29.7 \%$ of the urban area, while forests and forest cover area make up $10.2 \%$. The landscape-recreational complex of urban land use in the country reaches 726 thousand hectares or $54 \%$ of the land area of the cities.

Unlike settlements and industrial territories, the system of landscaping of the landscape-recreational complex, especially their monitoring, is characterized by the necessity of observing not only the state of the land fund but also the assessment of the ecological state of land resources regarding compliance with environmental safety requirements [10].

The ecological mechanism of protection of the landscape-recreation complex should include: environmental monitoring; environmental law enforcement of land use; environmental audit. The modern system of monitoring the land of cities is connected with the activities of urban ecological; land management and town-planning bodies, has departmental orientation. It does not contain the necessary information to predict the changes land use and development and implementation of recommendations for the prevention of negative phenomena [6].

Inspections of the state of use and protection of land in the process of self-regulatory land tenure contain mainly information on the unauthorized occupation of land, violation of the legal norms of acquiring rights to land, illegal construction of objects. For the protection of the land in Kyiv, for example, the Center for monitoring the construction of the Ukrainian capital was set up against illegal building. The portal of the Monitoring Center includes information on all construction objects, their legality is verified, and materials about bringing the perpetrators to responsibility are sent to environmental authorities, as well as to the court. Environmental monitoring works in cities are also carried out by environmental protection authorities.

The variety of types of monitoring and the subordination of their management to different departmental organizations does not allow to have complete comprehensive information about the monitoring object, which would be formed according to a single methodology, was comparable with the time of observation and in the spatial dimension. The specified goal can be achieved by way of environmental monitoring, which will be formed on the basis of a modern topographic and geodetic database, and will include monitoring information, most of which are ongoing but scattered by departments [8].

Environmental monitoring of land in cities should include: assessing the state of the dynamics of land use by category, owners, users of land, main types of land; analysis of the protection of lands of the landscape and recreation complex of cities (forest lands, especially protected lands, water, land for recreation of the population and agricultural land), their removal, changes in the purpose, compensation of the cost of losses of these lands; information on the pollution of land by heavy metals, chemicals, waste production; analysis of trends in pollution processes and development of proposals for their localization; state of water objects (coastal lines of rivers, seas, lakes, reservoirs), adherence to land use regimes and economic activities within water protection zones and coastal strips;

evaluation of processes related to the formation of ravines, landslides, karst, and other negative phenomena; the description of the territories occupied by the treatment facilities, fuel and lubricants, parking lots, the dumping of toxic industrial waste, landfills and other objects of household waste storage.

The ecological and legal support of the functioning of urban land use in modern conditions is associated with the need for the development of new right-wing acts that will ensure the environmentalization of land use and improve the procedures for compliance with environmental safety standards. These include the laws of Ukraine: a) on environmental monitoring of land resources; b) reservation and conservation of land; c) on the use of technogenically polluted land; d) on the reclamation of land; e) use of recreational land; e) on amendments to the legislation on compensation of losses of agricultural and forestry production, preservation of lands of the water fund and landscaping and recreational territories; e) on amendments to the legislation on increasing the liability for violation of the legislation on the use and protection of land.

Government decisions and regulatory acts of ministries should provide for regulation of the following issues: improvement of the procedure for seizure and granting of land plots in settlements; change in the 
order of compensation for losses of agricultural and forestry production with the use of materials normative monetary valuation of land and the expansion of forestland; introduction of norms of water fund losses associated with the occupation of land in the water management complex; Improving the assessment of agricultural land within settlements.

The environmental audit of environmental management should combine the issues of land use ecologization, which is now part of the control over the use and protection of land, is virtually unfulfilled and is one of the main reasons for the poor organization of land resources protection.

An environmental audit should be carried out exclusively by the central executive body, which implements the state policy on implementation of state supervision (control) in the field of environmental protection.

The economic mechanism for protecting land from unwarranted seizure is now based on a comparison of the achieved level the effect on the options for placing the object, taking into account the losses, as well as losses associated with land occupation, deterioration of the quality of land and restrictions on land use. The indicated mechanism also needs to be substantially improved.

\section{Conclusions}

The landscape-recreational potential of cities, which includes forests, especially protected areas, water, agricultural land and general use land, intended for recreation of the population, is $54 \%$ of the urban area and has a special value for maintaining the health of the population.

Protection of lands of the landscape-recreational complex of cities from unjustified seizure, as well as preservation of its species composition and quality status are considered as important factors of stabilization of the living environment and are strongly supported by the population of cities.

Ecological-economic mechanism of protection of the landscape-recreational complex should include: environmental monitoring; ecological and legal support of the operation of land use; environmental audit; economic substantiation of losses caused by the removal of agricultural, forest, water and recreational lands, restrictions on land use, land pollution and deterioration of their quality.

The variety of types of monitoring and subordination of their management to different departmental organizations does not allow to have complete and objective comprehensive information, which would be formed according to a single methodology, was comparable with the time of observations and in the spatial dimension. The specified goal can be achieved only by way of conducting environmental monitoring, which will be formed on the basis of the topographic and geodetic database and will include modern monitoring information, which will be supplemented with characteristics of the quality of land resources.

An environmental audit should be carried out exclusively by the central executive body, which carries out state supervision (control) in the field of environmental protection.

\section{Bibliography}

1. Holubets' M.A. Heosotsiosystemolohiya/M.A. Holubets'. — L'viv, 2013. - 264 s.

2. Hutsulyak H.D. Metodolohichni ta metodychni zasady optymizatsiyi pryrodokorystuvannya i zemlekorystuvannya/H.D. Hutsulyak, Yu.H. Hutsulyak//Zbalansovane pryrodokorystuvannya. - 2016. — \# 2. - S. $82-87$.

3. Derzhavni budivel'ni normy. - DBN $360-92^{* \star}$

4. Dobryak D.S. Klasyfikatsiya sil's'kohospodars'kykh zemel' yak naukova peredumova yikh ekolohobezpechnoho vykorystannya/D.S. Dobryak, O.P. Kanash, D.I. Babmindra, I.A. Rozumnyy. - K.: Urozhay, 2009. - $464 \mathrm{~s}$.

5. Natsional'na dopovid' shchodo zavershennya zemel'noyi reformy; za nauk. red. L.Ya. Novakovs'koho. K.: Ahrar. nauka. - 2015. - $48 \mathrm{~s}$.

6. Novakovs'ka I.O. Monitorynh sil's'kohospodars'koho zemlekorystuvannya/l.O. Novakovs'ka//Visn. ahrar. nauky. - 2016. - \# 4. - S. $69-75$.

7. Pro osnovni napryamy derzhavnoyi polityky Ukrayiny u haluzi okhorony dovkillya, vykorystannya pryrodnykh resursiv ta zabezpechennya ekolohichnoyi bezpeky: Postanova Verkhovnoyi Rady Ukrayiny vid 5 bereznya 1998 r. \# 188/98 - VR//Vidomosti Verkhovnoyi Rady Ukrayiny. — 1998. — \# 38 - 39. - S. 248.

8. Shevchuk V.Ya. Ekolohichne upravlinnya: [pidruchnyk]/V.Ya. Shevchuk, Yu.M. Satalkin, H.O. Bilyavs'kyy [ta in.]. - K.: Lybid', 2004. - $432 \mathrm{~s}$.

9. Furdychko O.I. Ahroekolohiya: [monohrafiya]/O.I. Furdychko. - K.: Ahrar. nauka, 2014 - $400 \mathrm{~s}$.

10. Furdychko O.I. Zemlya yak pryrodnyy resurs - nayvazhlyvishyy ob"yekt u vyrobnytstvi sil's'kohospodars'koyi i lisohospodars'koyi produktsiyi/ O.I. Furdychko, M.Kh. Shevchuk//Visn. ahrar. nauky. - 2011. -\# 8. - S. 5-9. 